\title{
E-Learning During the COVID-19 Outbreak: The Effect of the Grammar Translation Method and the Direct Method on Students' English Competence
}

\begin{abstract}
Kaharuddin
Faculty of Education and Teacher Training, Universitas Islam Negeri (UIN) Alauddin Makassar, Indonesia

Abstract-E-learning has been encouraged for usage during COVID-19, and this leaves problems with students' learning activities, particularly in social and economic aspects. Applying appropriate teaching methods is expected, which motivates students to learn virtually. This paper studies the effect of the grammar translation method and the direct method on students' English competence; the e-learning uses electronic tools with communication applications, such as Zoom and Google Classroom. The data were collected by questionnaires distributed to 100 students, of which 95 questionnaires were analyzable. The data were analyzed by path analysis via Microsoft SPSS version 21. The findings are as follows: 1) The grammar translation method has a significant direct effect on competence, contributing $\mathbf{2 7 . 7 \%}$ to students' English competence. The mediating role of Google Classroom has no contribution to the effect of the grammar translation method on students' English competence. 2) The direct method has an indirect effect on students' English competence, when utilized with the mediation of electronic tools that provide the Zoom application.
\end{abstract}

Index Terms - e-learning, grammar translation method, direct method, English competence

\section{INTRODUCTION}

It has been two years since learning-teaching processes have been conducted online by using technology as a tool for the learning process. It is called e-learning or virtual learning, and the lecturer and students are physically separated. During the e-learning of English, the learning process is considered to have decreased in the learning quality of students (Kaharuddin, Ahmad, D., Mardiana, Rusni. 2020). This reduction in learning quality is caused by many factors, especially those related to the smooth learning process. From an economic aspect, problems arise with the inability of students, especially those in low economic situations, to access the Internet, which means that some do not pass the course because they cannot join the virtual class. From a social aspect, students still need a face-to-face learning process where lecturers can take a social approach to students who are experiencing both economic and social problems. Student workload from lecturers in other subjects is another factor that can affect the improvement of students' English competence, because English as a soft skill with students' different language backgrounds requires discipline and learning time (Arafah, B., \& Kaharuddin, 2019). Additionally, the e-learning that has been implemented to date provides limited time and interaction between students and lecturers or other students. Network disturbances also often occur, which delay the learning process.

Huang, R., Tlili, A., Chang, T. W., Zhang, X., Nascimbeni, F., and Burgos, D. (2020) assert that there have been three main challenges in e-learning during the pandemic, namely, adjusting offline material to online formats, which takes time; lack of time for direct interaction between teachers and students; and motivating students to learn online. Furthermore, family influences and financial problems can interfere with the learning process of students (Byun, S., \& Slavin, R. E. 2020). In addition, Chitra, A. P., and Raj, M. A. (2018) state the disadvantages of e-learning, namely, lack of self-discipline in students; health problems that may produce straining problems, such as poor vision; and inability to access technology caused by poor Internet connections or environments in which it is difficult to access the Internet.

These problems cannot be avoided while the COVID-19 pandemic is still a global problem that can attack student health at any time. Government policies to prevent the spread of COVID-19 require the learning process to be conducted online. However, students' readiness to join and comply with the e-learning process is still in question, because the facts reveal the lack of students' participation and even presence in e-learning. Therefore, motivating students to learn English virtually and improve their English competence needs to be pondered wisely (Hasjim, M., Arafah, B., Kaharuddin, Verlin, S., \& Genisa, R. A. A. 2020).

Various efforts have been made to minimize the negative impacts caused by the challenges of e-learning. Carrillo, C., and Flores, M. A. (2020) reveal three elements that support the use of technology in the e-learning learning process: the pedagogical approach, learning design and facilities. The pedagogical approach is centered on efforts to further stimulate student learning activities where the teacher is a facilitator who designs the learning process as well as 
possible in which technology tools may be used so that students are motivated to learn. In this case, the learning model applied is assumed to contribute to the activation of student learning activities in the hope that their English competence can be improved (Andi, K., \& Arafah, B. 2017; Kaharuddin, K., \& Rahmadana, A. 2020). Hence, e-learning is providing a rare opportunity, producing changes in pedagogical strategies and improving the efficiency of teaching and learning (Cai, H. 2012).

Two models of learning and teaching English are highlighted in this research, namely, the grammar translation method (GTM), which is oriented to improve students' reading comprehension and writing competence, and the direct method (DM), which is oriented to improve students' listening and speaking competence. Combining the two methods in an e-learning process is an appropriate learning design with correlative material. Thus, students not only develop reading and writing competencies but also listening and speaking competencies on a particular theme being studied. Applying these two methods simultaneously in the virtual learning process requires technological aids, such as computers, laptops or mobile phones that provide communication applications such as Zoom, by which the lecturer and students interact directly and virtually, and Google Classroom, by which the lecturer assigns homework, writing exercises or reading comprehension exercises. Therefore, the two models used in one meeting are expected to improve students' English competence in listening, speaking, writing and reading comprehension.

The use of the two learning methods above in the online English learning process with technological aids is assumed to contribute to improving students' English competence. Therefore, the focus of this research is the use of the GTM and DM as independent variables and students' English competence as the dependent variable mediated by electronic tools, such as computers, laptops or mobile phones that provide Zoom and Google Classroom applications. This study highlights students' English competence as affected by the use of the GTM and DM in learning and teaching English virtually. The mediating role of e-learning with a computer, laptop or mobile device that provides Zoom and Google Classroom explains the effect of the two learning models on student competence, thus highlighting that direct and indirect effects of the two learning models on students' English competence.

\section{LITERATURE REVIEW}

\section{A. E-Learning of English}

E-Learning is widely used, particularly in modern English learning and teaching, which has been caused by COVID19; the pandemic has forced governments to issue policies of distance learning in which electronic media are used. Hence, e-learning is defined as a learning and teaching process that occurs online using the Internet. It is viewed as computer-assisted learning in which the learning content is delivered digitally. The information and communication systems, regardless of whether they are networked, are the specific media used to implement the learning process (Chitra, A. P., \& Raj, M. A. 2018). As it uses Internet technology to deliver education, e-learning is based on three criteria: 1) the ability to renew, store, distribute and share teaching material or information, 2) the delivery of information to every user via computer by using standard Internet technology, and 3) the focus on the broadest view of learning. However, the problem in e-learning is the absence of personal interactions between students and lecturers as well as between the students themselves (Young, J. R. 1997; Bahar, A. K., \& Latif, I. 2019).

E-learning of English means the learning and teaching of English through electronic media in which applications to facilitate the learning process are provided. In this case, the lecturer interacts with students virtually by using the technology, such as computers, laptops or notebooks through which assignments are sent to students via Google Classroom or WhatsApp. To interact verbally with students across distances, the communication application Zoom is used, and the grammatical exercises or reading comprehension exercises are sent through Google Classroom, which offers a feature through Google Docs to simplify students' tasks in the writing competence. Therefore, e-learning is web-based education that allows students to study without being physically present in class. Cai, H. (2012) concludes that e-learning could liberate the heavy labour of teachers and enable students to easily master English.

To stimulate student learning activities to improve English competence during e-learning, it is necessary to apply an appropriate learning method (Ismail, Sunubi, A. H., Halidin, A., Nanning, Kaharuddin. 2020). Considering that English language competence covers four skills-listening, speaking, writing and reading - the GTM and DM learning models are assumed to be able to motivate students' learning activities through virtual learning. Assignments for grammar and reading comprehension exercises are sent via Google Classroom, and listening and speaking practice are conducted through Zoom.

\section{B. The Grammar Translation Method in E-Learning of English}

The GTM is a traditional style of learning and teaching English in which lecturers usually require students to translate a text and understand the grammatical rules used in the text (Kaharuddin, A. 2018). This method relies on the activity of reading and translating text. It is widely used and applicable for large classes. Although it is a traditional method, it remains applicable; Elmayantie, C. (2015) highlights the reasons teachers use GTM in language learning. She finds that this method enables students to improve their English vocabulary and comprehend reading passages. Khan, A. B., Mansoor, H. S., and Manzoor, S. (2016) further mention that the GTM allows students who are learning English to become accustomed to and understand new vocabularies. 
The GTM uses the same techniques as other methods, including translating, reading to obtain information from a text, enriching vocabulary mastery by practicing antonyms and synonyms, using words in sentences and performing grammatical exercises (Larsen-Freeman, D. 2000; Bahar, K. 2013). As one strategy in the GTM, translation has a role in language learning (Stern, H. H., \& Allen, J. P. B. 1992) and contributes to the students' acquisition of the target language (Fazal, S., Majoka, M. I., \& Ahmad, M. 2016). Therefore, this method is helpful for teaching students the skills of writing and reading comprehension. In this research, this method is applied to teach writing and reading comprehension by using technology tools that provide Google Classroom, through which assignments on writing and reading comprehension are sent to students. Therefore, the following hypotheses are assumed:

Hypothesis 1: GTM has an effect on e-learning with communication applications in learning and teaching of English.

Hypothesis 2: GTM has a direct effect on students' English competence.

Hypothesis 3: GTM has an indirect effect through e-learning with communication applications.

\section{The Direct Method in E-Learning of English}

The DM is oriented to teach listening and speaking skills when the lecturer uses the language in the classroom directly and the students are listening. Translating the spoken sentences into the mother language if students do not understand is avoided; however, in such cases, the lecturer must have strategies to enable students to understand, such as visual aids or demonstrations (Titone in Chakrabarty, A. K., 2017). This method, which disseminates the language verbally and actively in classroom teaching, is ideal. Rather than focussing on the grammar rules, direct use of the language in the classroom must be encouraged, and grammar is included (Chakrabarty, A. K. 2017).

Norland, D. L., and Pruett-Said, T. (2006) propose several stages in implementing the DM in teaching English in higher schools. The stages are as follows: 1) the lecturer shows pictures to students to discuss; 2) the lecturer describes each picture in English; 3) the lecturer, speaking English, asks students about each picture; 4) students answer the questions in English. In short, for all activities during the learning process, students must use English verbally to improve listening and speaking skills. Virtual learning and teaching of English with the DM, as has occurred during COVID-19, provides room for these processes through Zoom. All learning participants may interact with each other directly and virtually. Therefore, the following hypotheses are assumed:

Hypothesis 4: DM has an effect on e-learning with communication applications in learning and teaching of English.

Hypothesis 5: DM has a direct effect on students' English competence.

Hypothesis 6: DM has an indirect effect through e-learning with communication applications.

Hypothesis 7: E-learning with communication applications has an effect on students' English competence

\section{Methodology}

This research is a quantitative descriptive study that aims to gather quantifiable information to present statistical analyses of a population sample (Abidin \& Kaharuddin. 2021). It involved 100 students from Economics Higher School of Bongaya in Makassar City, Indonesia. The variables were GTM $\left(X_{1}\right)$ and DM $\left(X_{2}\right)$ as the independent variables and English competence $\left(Y_{2}\right)$ as the dependent variable. E-learning using Zoom and Google Classroom as mediating variables $\left(Y_{1}\right)$ were employed to explain the causal relationship between the independent variables $\left(X_{1}\right.$ and $\left.X_{2}\right)$ and the dependent variable $\left(Y_{2}\right)$. The data were collected virtually through a questionnaire sent to the respondents via Google Classroom and email when the e-learning was conducted.

The data collected were analysed by using SPSS version 21. The research hypotheses were analysed by the following methods:

1. Instrument test. This test covers the validity test and reliability test. The validity test ensures that the research instrument is valid by correlating the value of each item and the total value of a variable using Pearson's correlation product moment $(r)$ with significance degree of $5 \%$. The reliability test analyses the consistency of the students in answering the questionnaire, which is calculated with Cronbach's alpha. The students were considered consistent in answering the questionnaire, and students' answers were considered reliable if the value of the Cronbach's coefficient alpha was above 0.6.

2. Classical assumption test. This test assesses normality and multicollinearity. The normality test examines the distribution of the residual variable in the regression model by using the Kolmogorov-Smirnov test. It is considered to be normally distributed if the value of Asymp. Sig. (2-tailed) Kolmogorov-Smirnov $Z>0.05$. Asymp. Sig. stands for Asymptotic Significance which refers to the test of probability value (p-value) to ensure that the tested distribution is not significantly deviating from the expected distribution of two-tailed. The multicollinearity test analyses whether the regression model contains a correlation between the two independent variables by using the variance inflation factor (VIF). If the value of the VIF is smaller than 10.00, then it means that there is no multicollinearity, and a tolerance value of greater than 0.10 means that multicollinearity exists.

3. Inferential statistical analysis. This test analyses the data by using partial analysis in SPSS version 21.

4. Hypothesis testing. The direct and indirect effects of the GTM and DM as independent variables on the students' English competence and on the dependent variable are tested. The hypotheses are

$\mathbf{H}_{\mathbf{0}}$ : Variables $X_{1}$ and $X_{2}$ have no direct effect on Variable $Y_{2}$.

$\mathbf{H}_{1}$ : Variables $X_{1}$ and $X_{2}$ have a direct effect on Variable $Y_{2}$ 


\section{FINDING AND DISCUSSION}

\section{A. Findings}

As stated in the methodology, questionnaires were used to collect the research data. There were 100 questionnaires distributed via Google Classroom. However, only 97 respondents returned the questionnaires, and among them, two were considered flawed and thus were not used in the data analysis. The validity of the questionnaires was tested by comparing the value of $r_{-}$table (the table containing correlation values or values of $r$ with which the value of $r$-calculation is compared to determine the significance level of the correlation test of Pearson Product Moment) and the value of $r$ calculation (the value of $r$ produced by SPSS test, a measure of linear correlation between two variables). In this research, only 95 questionnaires were analysed. The value of $r$-table was 0.202 taken from the table of $r$ values with a significance level of $5 \%$. This value was then compared with the value of $r$-calculation (the correlation value produced by SPSS test) to determine the validity of the questionnaire items.

Therefore, SPSS version 21 was used, which revealed that each item had correlation value above the value of $r_{\text {-table, }}$, and the value of $r$-calculation was greater than the value of $r_{\text {-table. }}$. This proved that the validity criteria had been fulfilled in all statements and in each research variable; therefore, the data could be scrutinised further. In the reliability test, the value of the reliability coefficient (Cronbach's alpha) was 0.396 , which was greater than the value of $r_{\text {-table }}(0.202)$, which means that the questionnaire items were reliable or consistent in providing the information required in this research. Hence, if this instrument is resubmitted in another study, the result will be the same as in this research.

Two classical assumption tests were exercised in this research. They are the normality test and multicollinearity test. For the normality test (using SPSS version 21), the value of Asymp. Sig. (2-tailed) for Kolmogorov-Smirnov was greater than $0.05(0.071>0.05)$. This indicated that the residual variable was normally distributed. Additionally, for the multicollinearity test, the tolerance value of each variable was greater than 0.10 and the value of the VIF was smaller than 10.00. In this case, the tolerance value of $X_{1}$ was 0.995 , which was greater than 0.10 , and the value of the VIF was 1.005 , which was less than 10.00 . The tolerance value of $X_{2}$ was 0.949 , which was greater than 0.10 , and the value of the VIF was 1.054, which was less than 10.00. The researcher concluded that there was no multicollinearity problem in the regression equation model used in this research.

In part analysis, the analysis was performed twice and thus produced two models: Model 1 and Model 2. In Model 1, the dependent variable is communication applications $\left(Y_{1}\right)$, and in Model 2, the dependent variable is students' English competence $\left(Y_{2}\right)$. This part analysis examined the direct and indirect effects of using $X_{1}$ and $X_{2}$ on students' English competence $\left(Y_{2}\right)$ with communication applications as the mediating variable $\left(Y_{1}\right)$. The two models produced are included below

\section{Model 1}

In Model 1, the communication application was the dependent variable, and the GTM and DM were the independent variables. The result of this part analysis of Model 1 is shown in Table 1.

TABLE 1
PART ANALYSIS MODEL 1
Coefficients

a. Dependent Variable: Computer Application

The table above shows the value of the standardised coefficient of the independent variables as part coefficient of $X_{1}$ and $X_{2}$. The part coefficient matrix is arranged as follows:

$$
\left(\begin{array}{l}
\rho y 1 x 1 \\
\rho y 1 x 2
\end{array}\right)=\left(\begin{array}{l}
0.071 \\
0.225
\end{array}\right)
$$

The part analysis of Model 1 also shows the value of the determinant coefficient as denoted in Table 2.

TABLE 2

DETERMINANT COEFFICIENT $\left(R^{2}\right)$ OF MODEL 1

\begin{tabular}{|l|l|l|l|l|l|}
\hline \multicolumn{1}{|c|}{ Model } & $R$ & $R$ Squared & Adjusted $R$ Square & $\begin{array}{l}\text { Std. Error of the } \\
\text { Estimate }\end{array}$ & Durbin-Watson \\
\hline 1 & $.236^{\mathrm{a}}$ & .056 & .035 & .25669 & 2.349 \\
\hline
\end{tabular}

a. Predictors: (Constant), DM, GTM

b. Dependent Variable: Computer Application 
The determinant coefficient as shown in the table above is 0.056. Calculating manually the value of $R$ squared changes the path coefficient matrix for $X_{1}$ and $X_{2}$ into row matrices, which are multiplied with the $Y_{1}$ column matrix. From the determination coefficient, the part coefficient of other variables outside the model can then be calculated: $p Y_{1 \varepsilon}$.

$$
\rho Y 1 \varepsilon=\sqrt{1-0.056=0.763}
$$

1) Path Coefficient of $\rho Y_{1} X_{1}$

The hypothesis of this part coefficient of $\rho Y_{1} X_{1}$ is:

$$
\text { 2) } \mathrm{H}_{\mathrm{o}}: \rho Y_{1} X_{1}=0
$$

For the part coefficient of $\mathrm{p} Y_{1} X_{1}$, namely, from the path $X_{1}$ to $Y_{1}$, Table 1 shows the column Sig. as 0.488 , which is greater than 0.05 . Therefore, $\mathrm{H}_{\mathrm{o}}$ is accepted and $\mathrm{H}_{1}$ is rejected which means that the part coefficient for $X_{1}$ to $Y_{1}$ is statistically not significant.

2) Path Coefficient of $\rho Y_{1} X_{2}$

$$
\begin{aligned}
& \mathrm{H}_{\mathrm{o}}: \rho Y_{1} X_{2}=0 \\
& \mathrm{H}_{1}: \rho Y_{1} X_{2} \neq 0
\end{aligned}
$$

For this part coefficient of $\mathrm{p} Y_{1} X_{2}$, namely, from the path $X_{2}$ to $Y_{1}$, Table 1 shows the column Sig. as 0.029 , which is smaller than 0.05 . Therefore, $\mathrm{H}_{\mathrm{o}}$ is refused and $\mathrm{H}_{1}$ is accepted, which means that the part coefficient for $X_{2}$ to $Y_{1}$ is statistically significant

\section{Model 2}

For the part analysis of Model 2, the students' English competence is the dependent variable, and the variables of GTM, DM and communication application are independent variables. The analysis result of Model 2 is presented in

\begin{tabular}{|c|c|c|c|c|c|c|c|c|}
\hline \multirow{2}{*}{\multicolumn{2}{|c|}{ Model }} & \multicolumn{2}{|c|}{ Unstandardised Coefficients } & \multirow{2}{*}{$\begin{array}{c}\text { Standardised } \\
\text { Coefficients } \\
\text { Beta }\end{array}$} & \multirow[b]{2}{*}{$t$} & \multirow[b]{2}{*}{ Sig. } & \multicolumn{2}{|c|}{ Collinearity Statistics } \\
\hline & & Beta & Std. Error & & & & Tolerance & VIF \\
\hline 1 & (Constant) & 3.345 & .418 & & 8.005 & .000 & & \\
\hline & DM & -.005 & .056 & -.009 & -.088 & .930 & .967 & 1.034 \\
\hline & GTM & .144 & .054 & .277 & 2.670 & .009 & .995 & 1.005 \\
\hline & ComApp & -.014 & .091 & -.016 & -.151 & .880 & .971 & 1.030 \\
\hline
\end{tabular}
Table 3 .

TABLE 3

The Result OF PATH ANALYSis Of MODEL 2 Coefficients $^{\mathrm{a}}$

a. Dependent Variable: English Competence

The table above shows the value of standardised coefficients for $X_{1}$ as 0.277 , for $X_{2}$ as 0.009 and for $Y_{1}$ as 0.016 . The matrix path coefficient is as follows:

$$
\left(\begin{array}{l}
\rho y 2 x 1 \\
\rho y 2 x 2 \\
\rho y 2 y 1
\end{array}\right)=\left(\begin{array}{l}
0.277 \\
0.009 \\
0.016
\end{array}\right)
$$

TABLE 4

DETERMINANT COEFFICIENT $\left(R^{2}\right)$ OF MODEL 2

\begin{tabular}{|c|r|r|r|r|r|}
\hline Model & $R$ & $R$ Squared & Adjusted $R$ Squared & $\begin{array}{c}\text { Std. Error of the } \\
\text { Estimate }\end{array}$ & Durbin-Watson \\
\hline 1 & $.206^{2}$ & .042 & .011 & .30997 & 1.936 \\
\hline
\end{tabular}

a. Predictors: (Constant), CompApp, GTM, DM

b. Dependent Variable: Eng Comp

The determinant coefficient is 0.042 , which can be manually calculated by altering the path coefficient matrices for $X_{1}, X_{2}$ and $Y_{1}$ to path matrices and then multiplying by the column matrix for $Y_{2}$. The path coefficient of other variables outside the model $\rho Y_{2 \varepsilon}$ is calculated:

$$
\mathrm{p} Y 2 \varepsilon=\sqrt{1-0.042=0.79}
$$

\section{1) Path Coefficient $\rho Y_{2} X_{1}$}

$$
\begin{aligned}
& \mathrm{H}_{\mathrm{o}}: \rho Y_{2} X_{1}=0 \\
& \mathrm{H}_{1}: \rho Y_{2} X_{1} \neq 0
\end{aligned}
$$

For the path $X_{1}$ to $Y_{2}$, the column Sig. in Table 3 is 0.009 , which is smaller than 0.05 , meaning that $\mathrm{H}_{1}$ is accepted and $\mathrm{H}_{\mathrm{o}}$ is rejected. 
2) Path Coefficient $\rho Y_{2} X_{2}$

$\mathrm{H}_{\mathrm{o}}: \rho Y_{2} X_{2}=0$

$\mathrm{H}_{1}: \rho Y_{2} X_{2} \neq 0$

The path coefficient $\rho Y_{2} X_{2}$ shows the column Sig. value is 0.930 , which is greater than 0.05 . It means that $\mathrm{H}_{1}$ is rejected and $\mathrm{H}_{\mathrm{o}}$ is accepted.

3) Path Coefficient $\rho Y_{2} Y_{1}$

$\mathrm{H}_{\mathrm{o}}: \rho Y_{2} Y_{1}=0$

$\mathrm{H}_{1}: \rho Y_{2} Y_{1} \neq 0$

For the path coefficient $\rho Y_{2} Y_{1}$, the column Sig. has a value of 0.880 , which is greater than 0.05 . It means that $\mathrm{H}_{1}$ is rejected and $\mathrm{H}_{\mathrm{o}}$ is accepted.

\section{Hypotheses Test}

Based on the data analysis about the effect of $X_{1}$ on $Y_{1}$, the significant value of $X_{1}$ is 0.488 , which is greater than 0.05 , and the value of $t$-calculation $(0.697)$ is smaller than the value of $t_{\text {-table }}(1.661)$ or $t$-calculation $<t$-table. It proves that the GTM has no effect on the e-learning with communication applications in learning and teaching of English. Therefore, Hypothesis 1 (GTM has an effect on e-learning with communication applications in learning and teaching of English) is rejected.

Furthermore, the result of the analysis of the effect of $X_{1}$ on students' English competence $\left(Y_{2}\right)$ denotes that the significant value of $X_{1}$ is 0.009 , which is smaller than 0.05 , and the value of $t$-calculation $(2.670)$ is greater than the value of $t_{\text {-table }}(1.661)$ or $t_{\text {-calculation }}>t_{\text {-table. }}$. It means that the GTM has a direct effect on students' English competence. Hence, Hypothesis 2 (GTM has a direct effect on students' English competence) is accepted.

Stated in Table 3, the direct effect of $X_{1}$ on $Y_{2}$ is 0.277 , and the indirect effect of $X_{1}$ through $Y_{1}$ on $Y_{2}$ is the multiplication of the $\beta$ value of $X_{1}$ on $Y_{1}$ with the $\beta$ value of $Y_{1}$ on $Y_{2}: 0.071 \times 0.016=0.001$. Therefore, the total effect of $X_{1}$ on $Y_{2}$ is the direct effect plus the indirect effect: $0.277+0.001=0.278$. It means that the direct effect is greater than the indirect effect of GTM on the students' English competence. It means the e-learning of English with communication applications offers no significant contribution to the effect of GTM on students' English competence. Hence, Hypothesis 3 (GTM has an indirect effect through e-learning with communication applications) is refused.

From the analysis of the effect of DM $\left(X_{2}\right)$ on e-learning with communication application in learning and teaching English $\left(Y_{1}\right)$, the significant value of $X_{2}$ is 0.029 , which is smaller than 0.05 , while the value of $t$-calculation $(2.225)$ is greater than the value of $t_{\text {-table }}(1.661)$ or $t$-calculation $>t_{\text {-table. }}$. It indicates that DM has an effect on e-learning with communication applications. Hence, Hypothesis 4 (DM has an effect on e-learning with communication applications in learning and teaching of English) is accepted.

With regard to the direct effect of DM $\left(X_{2}\right)$ on the students' English competence $\left(Y_{2}\right)$, the result shows that the significant value of $X_{2}$ is 0.930 , which is greater than 0.05 , and the value of $t$-calculation $(0.088)$ is smaller than the value of $t_{\text {-table }}(1.661)$ or $t_{\text {-calculation }}<t$-table. It means that DM has no direct effect on students' English competence. Hence, Hypothesis 5 (DM has a direct effect on students' English competence) is refused.

The direct effect of DM $\left(X_{2}\right)$ on students' English competence $\left(Y_{2}\right)$ is 0.009 , and the indirect effect of $X_{2}$ through $Y_{1}$ on $Y_{2}$ is the multiplication between the $\beta$ value of $X_{2}$ on $Y_{1}$ with the $\beta$ value of $Y_{1}$ on $Y_{2}: 0.225 \times 0.016=0.0036$. The total effect of $X_{2}$ on $Y_{2}$ is the direct effect plus the indirect effect: $0.009+0.0036=0.0126$. Therefore, the value of indirect effect is greater than the value of the direct effect, which means $X_{2}$ has an indirect effect on $Y_{2}$ that is mediated by $Y_{1}$. It means that DM has an indirect effect on students' English competence that is mediated by e-learning with communication applications. Hence, Hypothesis 6 (DM has an indirect effect through e-learning with communication applications) is accepted.

From the analysis of the effect of e-learning with communication applications on students' English competence, the research result shows that the significant value of $Y_{1}$ is 0.880 , which is greater than 0.05 , and the value of $t$-calculation (1.151) is smaller than the value of $t_{\text {-table }}(1.661)$ or $t_{\text {-calculation }}<t_{\text {-table. }}$ It means e-learning with communication applications has no effect on students' English competence. Hence, Hypothesis 7 (E-learning with communication applications has an effect on students' English competence) is rejected.

\section{B. Discussion}

The GTM and the DM have been widely used in learning and teaching English in higher schools. However, during the COVID-19 pandemic, teachers have been forced to carry out a virtual learning process using technology as a learning aid. Therefore, in this e-learning of English, Zoom and Google Classroom have been used to mediate the learning and teaching process. Its mediating role is expected to contribute to explaining the effect of the GTM and the DM on students' English competence.

To help students develop their online learning English competence, one of the determining factors is the use of learning methods that are expected to improve student learning outcomes, especially those relating to the development of English mastery competencies. Considering that English is a skill that includes listening, speaking, writing and reading, the GTM is used to teach writing and reading with electronics that have Google Classroom. This application is used to send assignments on grammar or reading comprehension, and the students must upload their answer in the same room. Concurrently, listening and speaking skills are taught by the DM via electronics that have the communication 
application by which the lecturer and students or students and other students are communicating in English. Thus, the four skills are related in the learning process at each meeting.

Research on the use of these two methods for virtual teaching of English with communication applications as a mediating variable reveals that the GTM in teaching writing and reading comprehension has a direct effect on students' English competence, with the standardised coefficient value of 0.277 , which is greater than 0.05 . It means that the use of GTM in learning English can contribute $27.7 \%$ to the improvement of students' English competence. The greater the value of the standardised coefficient, the greater the effect of GTM on students' English competence. The results of this study are in line with the research results of Khan, A. B., Mansoor, H. S., and Manzoor, S. (2016), which state that GTM has an effect on increasing writing and reading skills. Thus, the mediation of Google Classroom in explaining the effect of GTM on students' English competence did not make a significant contribution. Therefore, GTM is applicable in learning English offline, especially writing and reading comprehension, which is facilitated in the face-to-face learning process.

Furthermore, the DM as another independent variable whose effect on students' English competence was analysed demonstrates the standardised coefficient value of 0.009 , which was smaller than 0.05 . This means that DM only contributes $0.9 \%$ to the improvement of students' English competence. However, this method has an indirect effect of $1.26 \%$ through Zoom on students' English learning competence. This means that mediating e-learning with communication applications explains the effect of DM on students' English competence with a significant contribution, such that the DM in teaching English, especially listening and speaking, should use electronic aids with communication applications, such as the Zoom application

\section{CONCLUSION}

The conclusion of this research is that the GTM is more suitable in teaching English offline, because electronic mediation with applications such as Google Classroom does not have a significant effect in explaining the effect of GTM on students' English competence. The direct effect of this method on the students' English competence proves that this method is applicable for face-to-face learning processes in which students get direct information and explanation from the lecturer and may ask questions directly for things they do not understand and get immediate answers. However, the DM based on the research result has a significant positive effect on students' English competence when using electronic mediation with Zoom as a medium of communication between lecturers and students and between students and other students. For this reason, the DM is suitable for use in learning English during this COVID-19 pandemic, particularly in teaching listening and speaking skills.

\section{REFERENCES}

[1] Abidin \& Kaharuddin. (2021). Analysis of Syariah Credit Card from Islamic Economic Perspective: Evidence From BNI Bank In Indonesia. Academy of Strategic Management Journal, 20(4S), 1-11.

[2] Andi, K., \& Arafah, B. (2017). Using needs analysis to develop English teaching materials in initial speaking skills for Indonesian college students of English. The Turkish Online Journal of Design, Art and Communication (TOJDAC), Special Edition, 7, 419-436.

[3] Arafah, B., \& Kaharuddin. (2019). The Representation of Complaints in English and Indonesian Discourses. Opción, 35, 501517. https://doi.org/10.18502/kss.v3i19.4829

[4] Bahar, K. (2013). The Communicative Grammar Translation Method: An Integrated Method of CLT and GT for Teaching English Communicatively and Accurately. Yogyakarta: Trustmedia.

[5] Bahar, A. K., \& Latif, I. (2019). Society-based English community (sobat): EFL learners'strategy in learning and practicing English outside the walls. Jurnal ilmu budaya, 7(2), 255-265.

[6] Byun, S., \& Slavin, R. E. (2020). Educational responses to the COVID-19 outbreak in South Korea. Best Evid Chin Edu, 5(2), 665-680.

[7] Cai, H. (2012). E-learning and English Teaching. IERI Procedia, 2, 841-846.

[8] Carrillo, C., \& Flores, M. A. (2020). COVID-19 and teacher education: A literature review of online teaching and learning practices. European Journal of Teacher Education, 43(4), 466-487

[9] Chakrabarty, A. K. (2017). Teaching English through Direct Method and Grammar Translation Method at Upper Primary Level of Urban Backdrop: A Study of Correlation. International Journal in Management \& Social Science, 5(8), 300-307.

[10] Chitra, A. P., \& Raj, M. A. (2018). E-learning. Journal of Applied and Advanced Research, 3(S1), 11-13.

[11] Elmayantie, C. (2015). The use of grammar translation method in teaching English. Journal on English as a foreign language, 5(2), 125-132.

[12] Fazal, S., Majoka, M. I., \& Ahmad, M. (2016). Integration of grammar translation method with communicative approach: A research synthesis. International Research Journal of Arts \& Humanities (IRJAH), 44(44). 121-130.

[13] Hasjim, M., Arafah, B., Kaharuddin, Verlin,S, \& Genisa, R. A. A. (2020). Principles Behind Semantic Relation between Common Abbreviations and their Expansions on Instagram. International Journal of Criminology and Sociology, 9, 2270-2276.

[14] Huang, R., Tlili, A., Chang, T. W., Zhang, X., Nascimbeni, F., \& Burgos, D. (2020). Disrupted classes, undisrupted learning during COVID-19 outbreak in China: application of open educational practices and resources. Smart Learning Environments, $7(1), 1-15$.

[15] Ismail, Sunubi, A.H., Halidin, A., Nanning, Kaharuddin. (2020). Paraphrasing Technique to Develop Skill for English Writing Among Indonesian College Students of English. Systematic Reviews in Pharmacy, 11(11), 291-297. 
[16] Kaharuddin, A. (2018). The communicative grammar translation method: a practical method to teach communication skills of English. ETERNAL (English, Teaching, Learning, and Research Journal), 4(2), 232-254

[17] Kaharuddin, K., \& Rahmadana, A. (2020). Problem-Based Group Discussion: An Effective ELT Technique to Improve Vocational High School Students' Transactional Speaking Skills. Jurnal Ilmu Budaya, 8(2), 247-258.

[18] Kaharuddin, Ahmad, D, Mardiana, Rusni (2020). Contributions of Technology, Culture, And Attitude To English Learning Motivation During Covid -19 Outbreaks. Systematic Reviews in Pharmacy, 11 (11), 76-84. doi:10.31838/srp.2020.11.13

[19] Khan, A. B., Mansoor, H. S., \& Manzoor, S. (2016). The effectiveness of grammar translation method in teaching and learning of English language at intermediate level. International Journal of Institutional \& Industrial Research, 1(1), 22-25.

[20] Larsen-Freeman, D. (2000). Techniques and principles in language teaching. Oxford University.

[21] Norland, D. L., \& Pruett-Said, T. (2006). A kaleidoscope of models and strategies for teaching English to speakers of other languages. Greenwood Publishing Group.

[22] Stern, H. H., \& Allen, J. P. B. (1992). Issues and options in language teaching. Oxford University Press, USA.

[23] Young, J. R. (1997). Rethinking the Role of the Professor in an Age of High-Tech Tools. Chronicle of Higher Education, 44(6), A26-A28

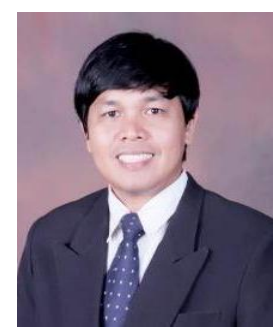

Kaharuddin was born in Makassar, Indonesia; on August $14^{\text {th }}, 1975$. He got his master's degree in English Language Studies in 2004 and his doctoral degree in Applied Linguistics in 2014, both from Hasanuddin University of Makassar, Indonesia. He is currently a senior lecturer in English Language Teaching and Linguistics at the English Education Department, Faculty of Education and Teacher Training, Universitas Islam Negeri (UIN) Alauddin Makassar, Indonesia. He is the author of a number of books, including: Syllabus Design for English Language Teaching, Prenada Media (2018); It's All About Transactional Speaking Skills, Eliva Press, Moldova Europe (2021); and Linguistics: Basic theory and Roles in ELT, Prenada Media (2021). His research focuses on English education and Linguistics.

Dr. Kaharuddin is currently a member of ASIA TEFL Association, Busan, South Korea. 